\title{
Watershed Scale Response to Climate Change_-Cathance Stream Basin, Maine
}

\section{Introduction}

General Circulation Model (GCM) simulations of future climate through 2099 project a wide range of possible scenarios (Intergovernmental Panel on Climate Change, 2007). To determine the sensitivity and potential effects of long-term climate change on the freshwater resources of the United States, the U.S. Geological Survey Global Change study, "An integrated watershed scale response to global change in selected basins across the United States" was started in 2008. The long-term goal of this national study is to provide the foundation for hydrologically based climate-change studies across the nation.

Fourteen basins for which the Precipitation Runoff Modeling System (PRMS) has been calibrated and evaluated were selected as study sites. PRMS is a deterministic, distributedparameter watershed model developed to evaluate the effects of various combinations of precipitation, temperature, and land use on streamflow and general basin hydrology. Output from five GCMs and four emission scenarios were used to develop an ensemble of climate-change scenarios for each basin. These ensembles were simulated with the corresponding PRMS model. This fact sheet summarizes the hydrologic effects and sensitivity of the PRMS simulations to climate change for the Cathance Stream Basin at Edmunds, Maine (U.S. Geological Survey streamflow-gaging station 01021230; fig. 1) presented in the project summary report (Markstrom and others, 2012) and a journal article (Hay and others, 2011).

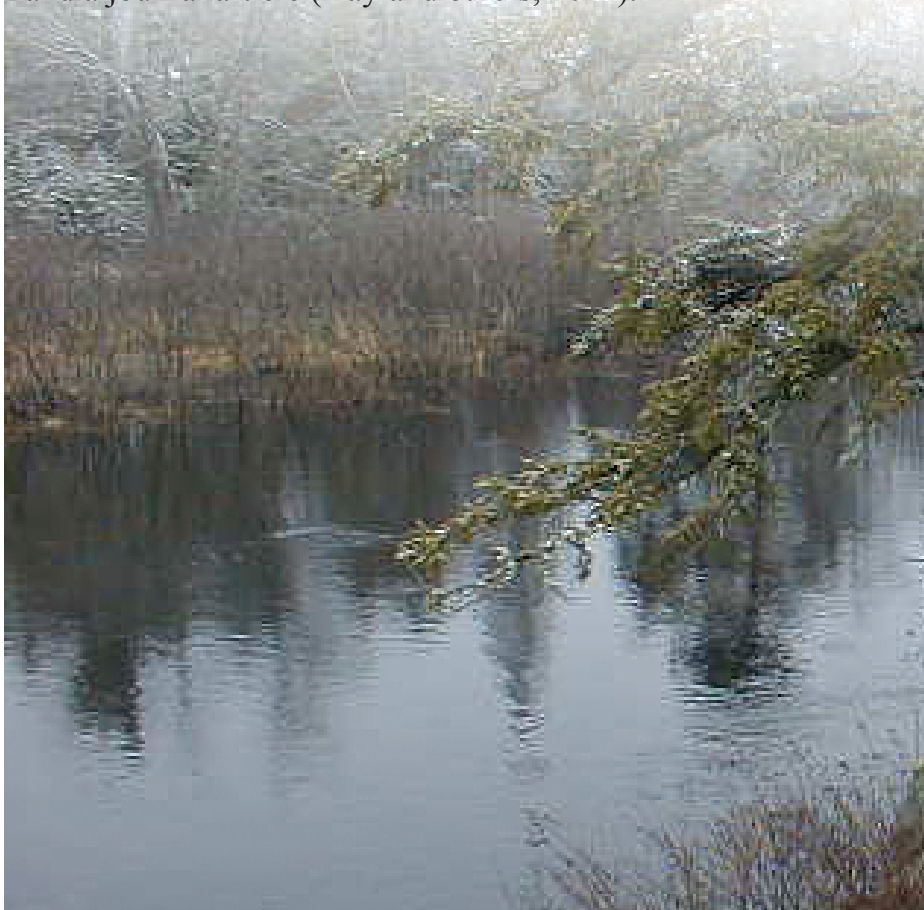

\section{Study Area}

The Cathance Stream is an 85 -square kilometer $\left(\mathrm{km}^{2}\right)$ basin in Washington County, eastern Maine, on the coast of the Atlantic Ocean. The stream is a tributary to the Dennys River. The basin is rural and its rolling topography predominantly is forested with wetlands, lakes, ponds, blueberry agriculture fields, clear cuts, partial cuts, regenerating forest, and light residential development. The climate is temperate, with mild summers and cold winters; normal mean annual air temperature is about 7 degrees Celsius $\left({ }^{\circ} \mathrm{C}\right)$, with mean monthly air temperatures ranging from about $-29^{\circ} \mathrm{C}$ in January to about $19^{\circ} \mathrm{C}$ in July. Mean annual precipitation is approximately 114 centimeters $(\mathrm{cm})$ and is distributed fairly evenly throughout the year. Mean annual evapotranspiration (loss of water to the atmosphere by evaporation from the soil and transpiration from plants) is about $46 \mathrm{~cm}$.

The Dennys River and Cathance Stream are important habitat for wild Atlantic salmon. Currently (2011), wild Atlantic salmon populations are protected under the U.S. Endangered Species Act of 1973 (16 USC Sec. 1531) and are the subject of a comprehensive recovery program. The U.S. Geological Survey, in cooperation with the Maine Department of Marine Resources Bureau of Sea Run Fisheries and Habitat, began a study in 2004 to characterize the quantity, variability, and timing of streamflow in the Dennys River (Dudley, 2008). The study included the development and evaluation of a distributed-parameter watershed model (PRMS). The watershed modeling work supports several tasks directed at developing water-use management plans for Atlantic salmon rivers and development of comprehensive flow monitoring in these basins. Improved water-resources information supports Atlantic salmon protection efforts.

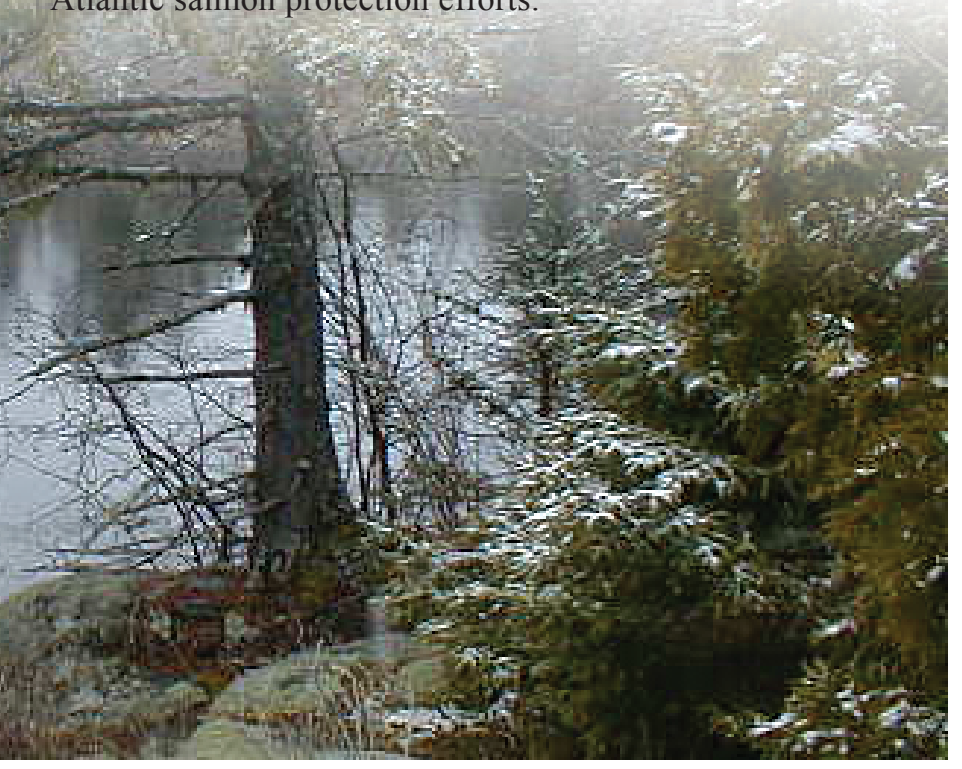



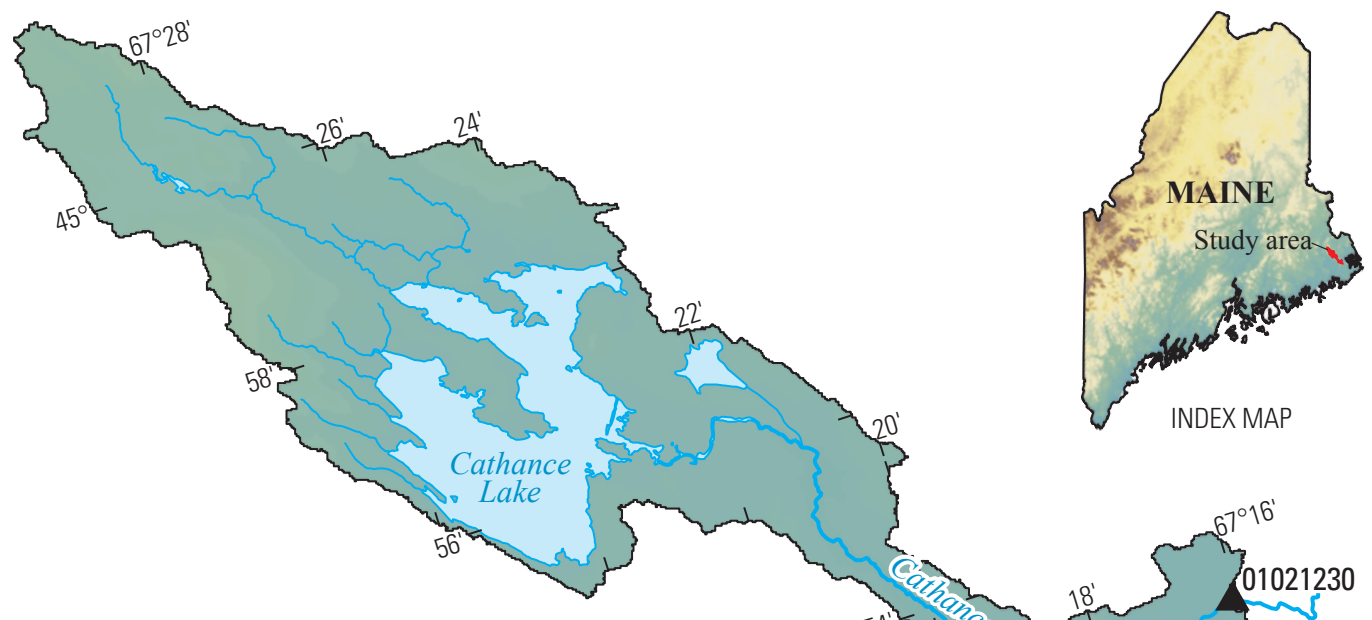

Base from U.S. Geological Survey digital data, 2011 1:100,000 Albers Equal-Area Conic projection Standard parallels $29^{\circ} 30^{\prime} \mathrm{N}$ and $45^{\circ} 30^{\prime} \mathrm{N}$

Central meridian $96^{\circ} 00^{\prime} \mathrm{W}$, Latitude of origin $23^{\circ} 00^{\prime} \mathrm{N}$

Horizontal coordinate information is referenced to the World Geodetic System of 1984 (WGS 84)

\section{EXPLANATION}

Elevation in meters

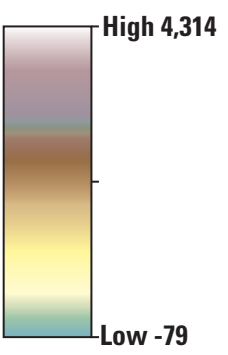

U.S. Geological Survey streamflow-

gaging station and identifier

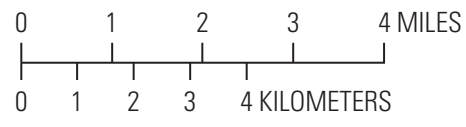

Figure 1. Precipitation Runoff Modeling System study locations, Cathance Stream Basin, Maine, and location of U.S. Geological Survey streamflow-gaging station 01021230 with a drainage area of 85 square kilometers and elevation range from 46 to 174 meters.

\section{General Circulation Models}

Given the uncertainty in climate modeling, it is desirable to use more than one GCM to obtain a range of potential future climatic conditions. Monthly precipitation and temperature output from five GCMs were processed (table 1).

Table 1. General Circulation Model (GCM) projections used in this study.

\begin{tabular}{ll}
\hline \multicolumn{1}{c}{ GCM } & \multicolumn{1}{c}{ Center and country of origin } \\
\hline BCC-BCM2.0 & Bjerknes Centre for Climate Research, Norway \\
CSIRO-Mk3.0 & Australia's Commonwealth Scientific and Industrial Research Organization, Australia \\
CSIRO-Mk3.5 & Australia's Commonwealth Scientific and Industrial Research Organization, Australia \\
INM-CM3.0 & Institute for Numerical Mathematics, Russia \\
MIROC3.2 & National Institute for Environmental Studies, Japan \\
\hline
\end{tabular}


The GCM outputs were obtained from the World Climate Research Programme's Coupled Model Intercomparison Project phase 3 multi-model dataset archive, which was referenced in the Intergovernmental Panel on Climate Change Fourth Assessment Special Report on Emission scenarios (Intergovernmental Panel on Climate Change, 2007). For each GCM, one current (water years 1988-1999) and three future emission scenarios were used and are described in table 2.

Table 2. Climate-change emission scenarios simulated by the General Circulation Models in this study.

\begin{tabular}{ll}
\hline \multicolumn{1}{c}{ Emission scenario } & \multicolumn{1}{c}{ Description/assumptions } \\
\hline 20C3M & $\begin{array}{l}\text { 20th century climate used to determine baseline (1989-1999) conditions } \\
\text { Rapid economic growth, a global population that peaks in mid-21st century and rapid introduction of new and } \\
\text { more efficient technologies with a balanced emphasis on all energy sources } \\
\text { Convergent world, with the same global population as Emission scenario A1B, but with more rapid changes in } \\
\text { economic structures toward a service and information economy that is more ecologically friendly } \\
\text { B1 }\end{array}$ \\
Aeterogeneous world with high population growth, slow economic development, and slow technological change
\end{tabular}

Climate-change fields were derived by calculating the change in climate from current (water years 1988-1999) to future conditions simulated by each GCM. The 20C3M simulation for water years 1988-1999 was used to represent current climatic conditions. This 12-year period of record was chosen based on the overlap of the available historical records from the 14 basins included in the national study. Climate change fields (percentage changes in precipitation and degree changes in temperature) were computed for 12 -year moving window periods (from 2001-2099) using the 20C3M (1988-1999) and the A1B, B1, and A2 emission scenarios. A 12-year moving window, starting in 2001 and ending in 2099, results in 1,320 future scenarios $[(88,12$-year climatologies, 1 per year starting with 2001-2012 and ending with 2088-2099) x (3 emission scenarios) $\mathrm{x}$ (5 GCMs)].

Climate-change scenarios were generated for PRMS by modifying PRMS precipitation and temperature inputs with the mean monthly climate change fields derived from the GCMs, resulting in 1,320 PRMS-input files. Table 3 shows the change (slope) and adjusted $\mathrm{R}^{2}(\operatorname{adj} \mathrm{R} 2)$ for the least squares fit to the trend line for selected output variables from the PRMS projections. The slope indicates the change in the selected variable by year. The adjusted $\mathrm{R}^{2}$ value gives an indication of the variability in the central tendency of the trend line.

Figure 2 shows a summary of the projected range in 11-year moving mean daily values of maximum temperature (fig. $2 A$ ), minimum temperature (fig. $2 B$ ), and precipitation (fig. $2 C$ ) by emission scenario. The first year of each 12 -year simulation was used as PRMS initialization and is not included in the results. The three solid-colored lines indicate the 11-year moving mean values (x-axis indicates center of 11-year window) for the three future emission scenarios (central tendency of the five GCMs for each emission scenario). The projected range shown for each emission scenario indicates the range of potential future climatic conditions simulated by the five GCMs. All GCM simulations project steady increases in maximum and minimum temperature (table 3), with uncertainties associated with these GCM projections increasing with time. Both maximum and minimum temperatures show the smallest projected annual changes for the B1 emission scenario. Projected annual changes in precipitation are variable, with projected increases in the central tendencies by the end of the 21 st century for the A1B and A2 emission scenarios (table 3 ).

\section{Results}

PRMS simulates spatially distributed streamflow, components of flow (surface, subsurface, and groundwater), snowpack conditions, and many other hydrologic components of interest. Figure 3 shows the projected range in 11-year moving mean daily values of streamflow by emission scenario. The central tendencies of the PRMS simulations using the emission scenarios project decreases in mean annual streamflow for the A1B and $\mathrm{A} 2$ emission scenarios (table 3), though the uncertainties associated with these streamflow projections are large.

Because of the increase in temperatures, the percentage of precipitation that falls as snow (fig. $4 A$ ), snowpack water equivalent (fig. $4 B$ ), and snowmelt (fig. $4 C$ ) are projected to decrease in the basin on an annual basis, with high variability (table 3). The changes in snowpack accumulation and melt will in turn affect the seasonal amount and timing of streamflow.

Displaying basin mean streamflow by month (fig. 5) illustrates the projected change in the seasonal distribution of streamflow resulting from projected changes in snowpack accumulation and melting (fig. 4). The solid red lines in figure 5 show PRMS-simulated mean monthly streamflow for current conditions (1989-1999). The boxplots represent the range in projected mean monthly streamflow for the five GCMs and three scenarios for 2030 (green, 2025-2035), 2060 (tan, 2055-2065) and 2090 (blue, 2085-2095). Large increases in streamflow are projected for January through March, while large decreases are projected for April through June. The timing of peak streamflow for current conditions (1989-1999, red line) occurs in April. By the end of the 21st century, peak timing of streamflow could occur as early as January based on the projections in figure 5 . The range of values indicated by the 

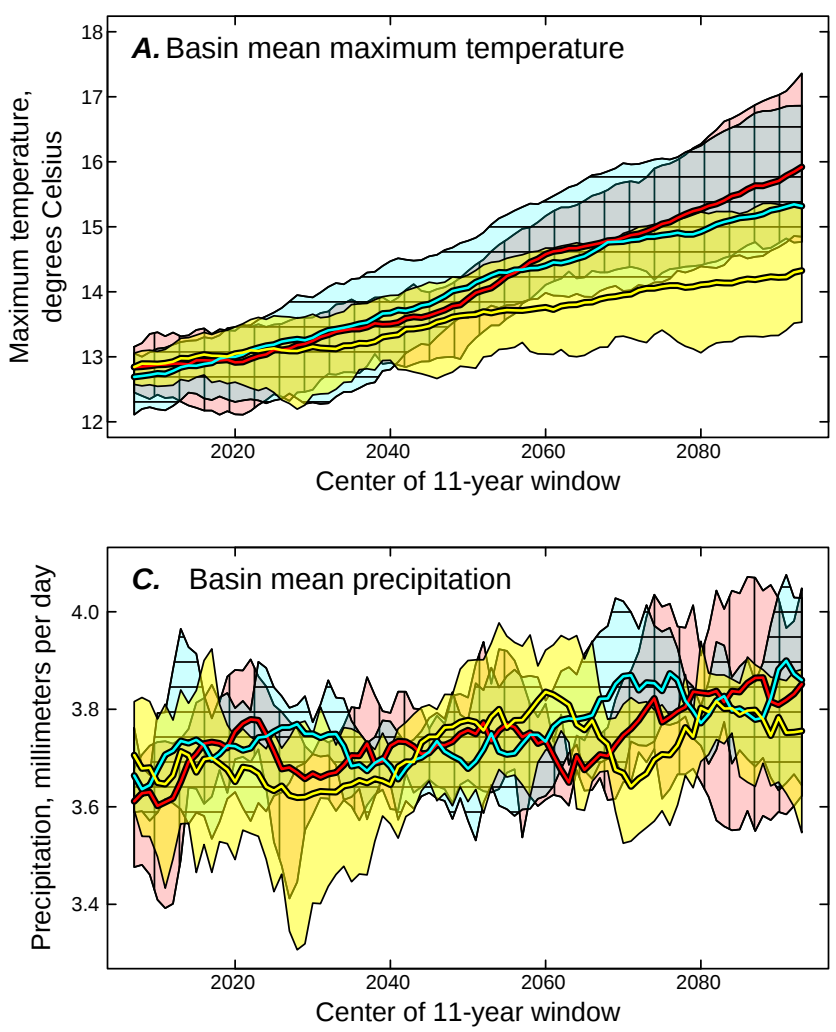

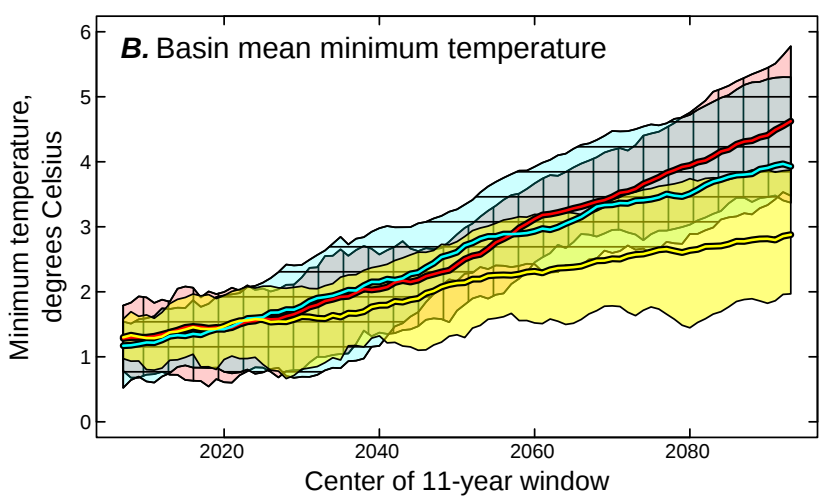

EXPLANATION

Emission Scenarios

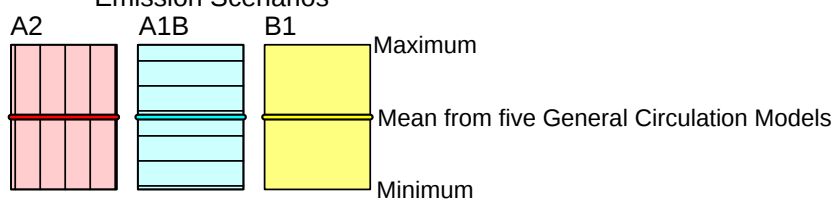

Figure 2. Projected range in 11-year moving mean daily values of $(A)$ maximum temperature, $(B)$ minimum temperature, and (C) precipitation by emission scenario.

Table 3. Projected change by year (slope) and adjusted $R^{2}$ (adjR2) based on the central tendencies of the five General Circulation Models for the three carbon emission scenarios for selected Precipitation Runoff Modeling System (PRMS) output variables.

[Blue indicates a significant negative trend and yellow indicates a significant positive trend $(\mathrm{p}<0.05)$ accounting for lag-1 autocorrelation].

\begin{tabular}{|c|c|c|c|c|c|c|}
\hline \multirow{2}{*}{ PRMS output variable } & \multicolumn{2}{|c|}{$\begin{array}{c}\text { Emission scenario } \\
\text { A1B } \\
\end{array}$} & \multicolumn{2}{|c|}{$\begin{array}{c}\text { Emission scenario } \\
\text { A2 } \\
\end{array}$} & \multicolumn{2}{|c|}{$\begin{array}{c}\text { Emission scenario } \\
\text { B1 } \\
\end{array}$} \\
\hline & slope & adjR2 & slope & adjR2 & slope & $\operatorname{adjR2}$ \\
\hline Maximum temperature in degrees Celsius & 0.033 & 0.99 & 0.038 & 0.98 & 0.018 & 0.98 \\
\hline Minimum temperature in degrees Celsius & 0.035 & 0.99 & 0.041 & 0.98 & 0.020 & 0.98 \\
\hline Precipitation in millimeters per day & 0.0019 & 0.56 & 0.0019 & 0.58 & 0.0016 & 0.40 \\
\hline Streamflow in cubic meters per second & -0.0029 & 0.78 & -0.0038 & 0.84 & -0.0012 & 0.35 \\
\hline Percent snow in percent per day & -0.12 & 0.98 & -0.13 & 0.99 & -0.07 & 0.95 \\
\hline Snowpack water equivalent in millimeters per day & -0.28 & 0.95 & -0.29 & 0.98 & -0.17 & 0.94 \\
\hline Snowmelt in millimeters per day & -0.0039 & 0.95 & -0.0047 & 0.97 & -0.0021 & 0.93 \\
\hline
\end{tabular}

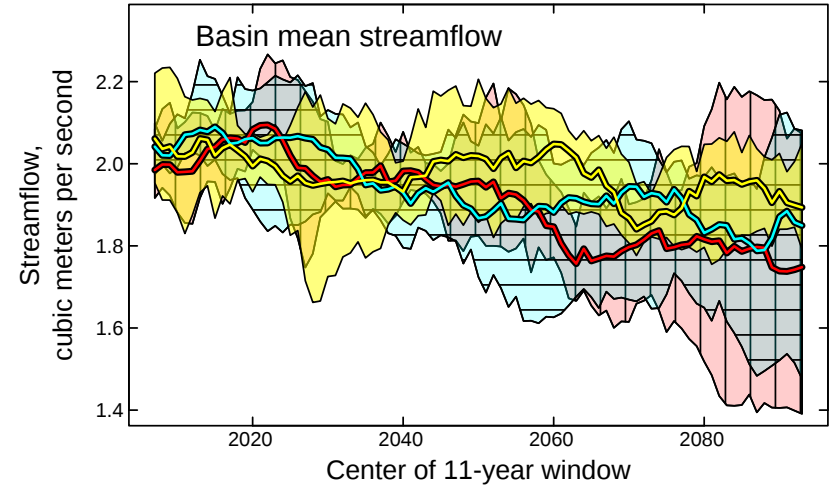

\section{EXPLANATION}

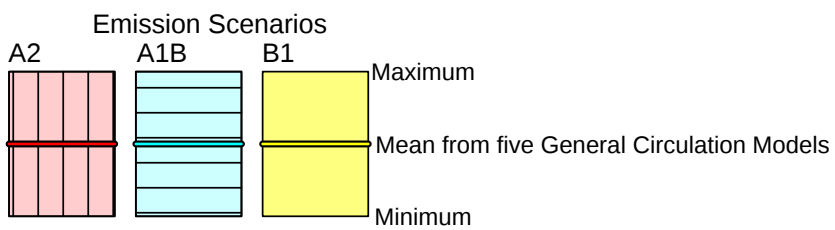

Figure 3. Projected range in 11-year moving mean daily values of streamflow by emission scenario. 

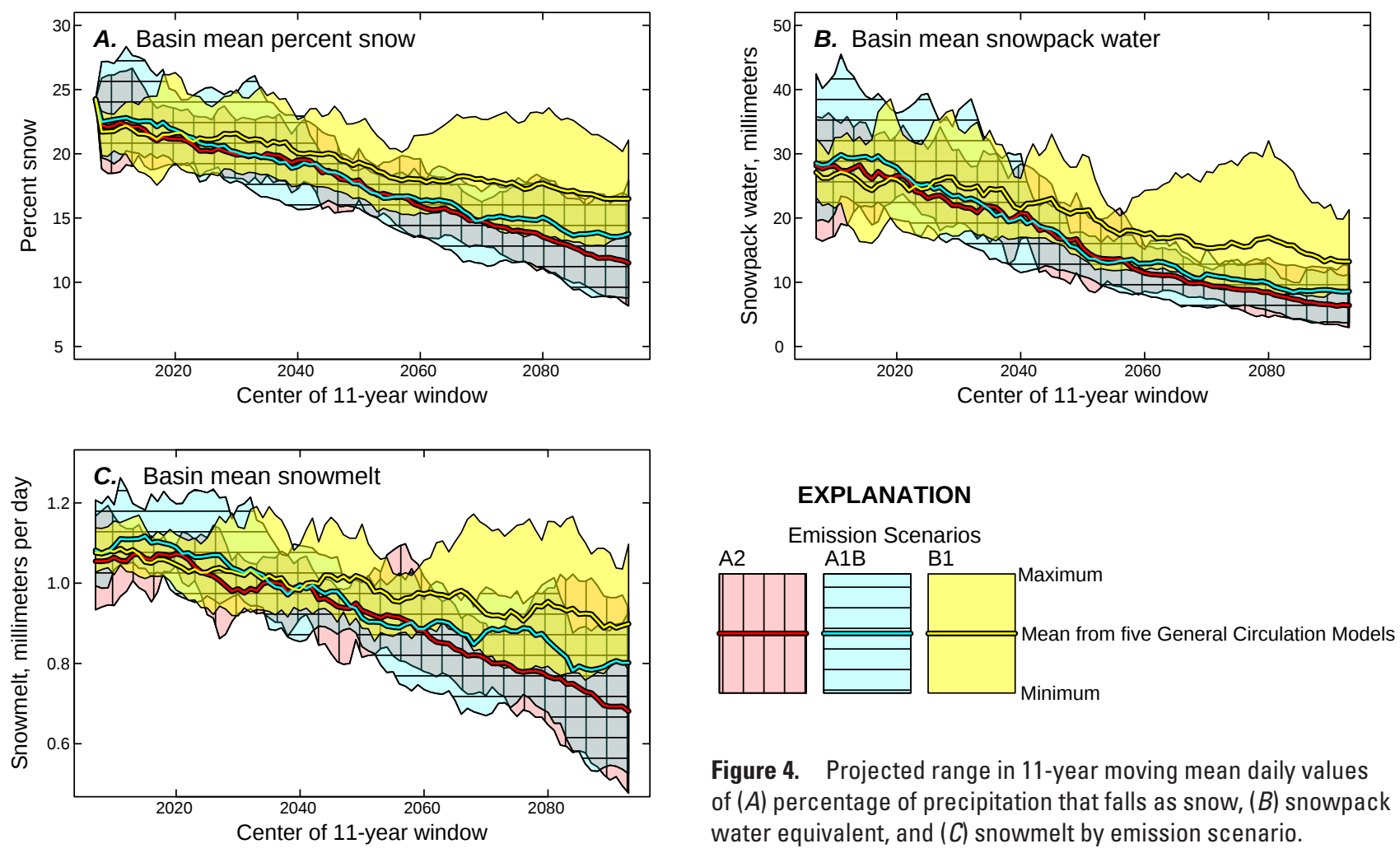

Figure 4. Projected range in 11 -year moving mean daily values of $(A)$ percentage of precipitation that falls as snow, $(B)$ snowpack water equivalent, and $(C)$ snowmelt by emission scenario.
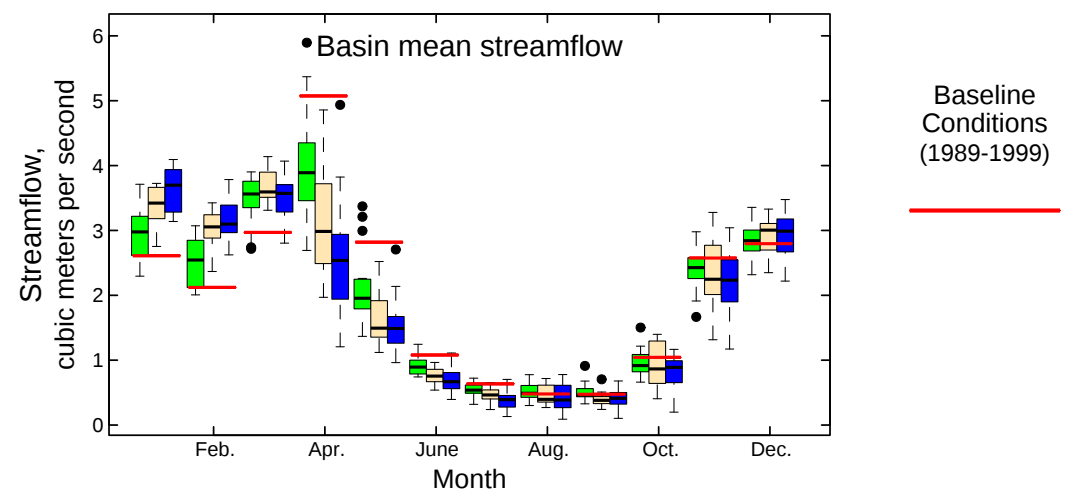

\section{EXPLANATION}

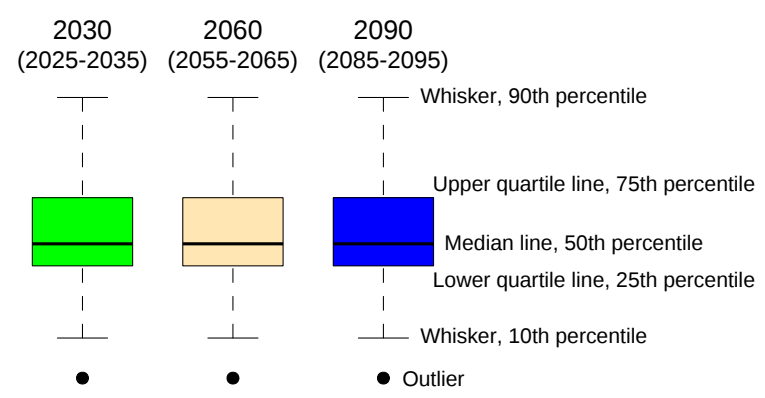

Figure 5. Mean daily streamflow values by month for baseline conditions and projected range $(2030,2060$, and 2090) using the five General Circulation Models and three emission scenarios.

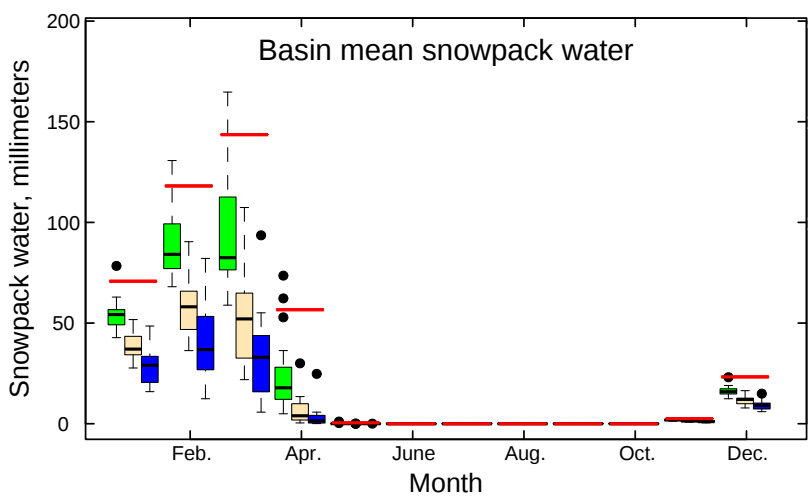

Figure 6. Mean daily snowpack water equivalent values by month for baseline conditions and projected range $(2030,2060$, and 2090) using the five General Circulation Models and three emission scenarios. boxplots in figure 5 illustrates the high degree of uncertainty associated with the magnitude of these projected streamflow changes, in all but the summer months. This trend is consistent with projected decreases in snowpack water equivalent (fig. 6). Snowpack is expected to decrease because of more snowmelt and more precipitation falling as rain during the winter (November through March) months. This advance in spring snowmelt runoff has been documented in the historical record with winterspring streamflow becoming significantly earlier in northern and mountainous sections of Maine during the 20th century (Dudley and Hodgkins, 2002; Hodgkins and others, 2003; Hodgkins and Dudley, 2006a). Over a 50-year historical period, 18 of 23 snow-course sites in and near Maine had a significant decrease $(p<0.1)$ in late-winter snowpack depth, or an increase in snowpack density (Hodgkins and Dudley, 2006b). PRMSmodel results indicate these trends are expected to continue. 


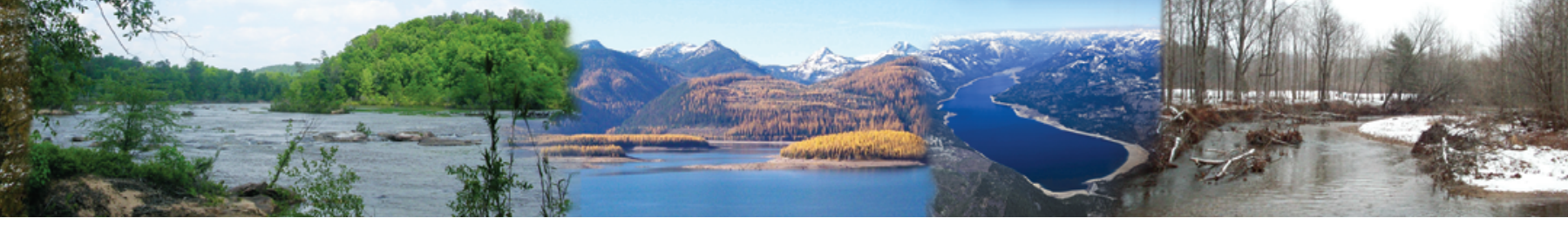

\section{Conclusion and Discussion}

The Cathance Stream tributary of the Dennys River Basin, and other coastal river basins in Maine, are important habitat for a variety of aquatic species including endangered Atlantic salmon. The broader-scale consequences of climate change on the flow regimes of rivers in Maine, like Cathance Stream, likely will affect ecosystems. The ecological implications of changes in the timing of winter-spring streamflow in Maine are not well understood. One possible effect may be a change in Atlantic salmon survival rates. If the peak spring migration of juvenile salmon from freshwater rivers (which is controlled by photoperiod, temperature, and flow) becomes out of phase with optimal environmental conditions in the rivers, the estuaries, or the ocean, salmon survival could drop substantially (McCormick and others, 1998). Changes in the timing of spring river flows also may effect fresh-water mixing in estuarine ecosystems. Earlier snowmelt and increases in summer evapotranspiration rates (not shown) could shorten the annual periods of standing water pools which are used by amphibians for breeding in forested depressional wetlands (called vernal pools). The scientific techniques described in the fact sheet can be augmented with other techniques in developing the science needed to address the effects of climate change on water resources and ecosystems.

\section{By Robert W. Dudley, Lauren E. Hay,} Steven L. Markstrom, and Glenn A. Hodgkins

For more information visit the following Web sites: http://wwwbrr.cr.usgs.gov/projects/SW_MoWS/

http://me.water.usgs.gov/

http://www.usgs.gov/climate_landuse/

\section{Selected References}

Dudley, R.W., 2008, Simulation of the quantity, variability, and timing of streamflow in the Dennys River Basin, Maine, by use of a precipitation-runoff watershed model: U.S. Geological Survey Scientific Investigations Report 2008-5100, 44 p.

Dudley, R.W., and Hodgkins, G.A., 2002, Trends in streamflow, river ice, and snowpack for coastal river basins in Maine during the 20th century: U.S. Geological Survey WaterResources Investigations Report 02-4245, 26 p.

Hay, L.E., Markstrom, S.L., and Ward-Garrison, C.D., 2011, Watershed-scale response to climate change through the twenty-first century for selected basins across the United States, Earth Interactions, v. 15, 37 p.

Hodgkins, G.A., Dudley, R.W., and Huntington, T.G., 2003, Changes in the timing of high river flows in New England over the 20th century: Journal of Hydrology, v. 278, p. $242-250$.

Hodgkins, G.A., and Dudley, R.W., 2006a, Changes in the timing of winter-spring streamflow in eastern North America, 1913-2002: Geophysical Research Letters, v. 33, L06402, doi: 10.1029/2005GL025593.

Hodgkins, G.A., and Dudley, R.W., 2006b, Changes in latewinter snowpack depth, water equivalent, and density in Maine, 1926-2004: Hydrological Processes, v. 20, p. 741-751.

Intergovernmental Panel on Climate Change, 2007, Summary for policymakers, in Climate change 2007-The physical science basis, Contributions of Working Group 1 to the Fourth Assessment Report of the Intergovernmental Panel on Climate Change: Cambridge and New York, Cambridge University Press, $18 \mathrm{p}$.

Markstrom, S.L., Hay, L.E., Ward-Garrison, C.D., Risley, J.C., Battaglin, W.A., Bjerklie, D.M., Chase, K.J., Christiansen, D.E., Dudley, R.W., Hunt, R.J., Koczot, K.M., Mastin, M.C., Regan, R.S., Viger, R.J., Vining, K.C., and Walker, J.F., 2012, An integrated watershed scale response to climate change for selected basins across the United States: U.S. Geological Survey Scientific Investigations Report 2011-5077, 142 p.

McCormick, S.D., Hansen, L.P., Quinn, T.P., and Saunders, R.L., 1998, Movement, migration, and smolting of Atlantic salmon (Salmo salar): Canadian Journal of Fisheries and Aquatic Science, v. 55 (Suppl. 1), p. 77-92. 